\title{
A mikrotörténelem módszertanáról
}

\author{
About the Methodology of Microhistory

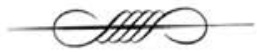 \\ Szijártó M. István (2014): \\ A történész mikroszkópja. A mikrotörténelem elmélete és gyakorlata. \\ Budapest, L'Harmattan Kiadó. 272 o.
}

DOI 10.14232/belv.2018.1.12 https://doi.org/10.14232/belv.2018.1.12

Cikkre való hivatkozás / How to cite this article: Lakatos Artúr (2018): A mikrotörténelem módszertanáról. Belvedere Meridionale 30. évf. 1. sz. 189-190. pp

ISSN 1419-0222 (print) ISSN 2064-5929 (online, pdf)

(Creative Commons) Nevezd meg! - Így add tovább! 4.0 (CC BY-SA 4.0)

(Creative Commons) Attribution-ShareAlike 4.0 International (CC BY-SA 4.0)

www.belvedere-meridionale.hu

Jelen kötet arra példa, hogyan lehet jól sikerült előtanulmányok alapján egy még jobb könyvet megírni. A What is Microhistory? Theory and practice az én kezemben is megfordult már, de leginkább az Erős Vilmos és Takács Ádám szerkesztette Tudomány és ideológia között című kötetből emlékszem Szijártó szintézis jellegủ tanulmányára. Külön felfigyeltem benne Szijártó Istvánnak az olasz és az angolszász mikrohistóriai iskolákkal kapcsolatos gondolataira. E kutatásait kerekítette ki a szerző ebben kötetben, egy átfogó monográfiává alakítva át korábbi mikrohistóriai kutatásait, elsősorban a módszertani ismeretek terén kidomborítva tudását.

A kötet bibliográfiája terjedelmes, és összehasonlítva a bibliográfiában foglalt címeket a lábjegyzetek gazdagságával, megállapítható, hogy a szerző, amit olvas, idézi is, és nem is kis mértékben. Több esetben is - ilyen a Carlo Ginzburgé is - oldalakon át idéz, értelmez, vitába száll, következtetéseket von le a forrást jelentő munkával kapcsolatban. Teszi ezt úgy, hogy az egyedi, szerzőre vagy konkrét forrásra vonatkozó mondanivalóját egy szintetikus összefoglaló képbe 
harmonikusan integrálja (ezzel a képességgel nem minden történetíró rendelkezik). Mivel a kötet elsősorban a történetírás kérdésében alkot, természetes, hogy forrásai, elemzésének tárgyai elsősorban már megjelent könyvek és tanulmányok. A bibliográfiai listát végigböngészve a legnagyobb a magyar szerzők által irt vagy magyarra is lefordított, külföldi szerzők szellemi termékét képező könyvek mennyisége, ezt követik az angol nyelvű címek, de találhatunk francia, német, orosz, spanyol vagy dán nyelvü kiadásokra is hivatkozásokat.

A kötet szerkezetét illetően, tematikus fejezetekbe tagolt. Egy rövid bevezetőt követően külön fejezet szól az olasz mikrotörténelem - microistoria - módszertani hagyományairól és témáiról, ezt követi egy fejezetbe foglalva a német és a francia mikrotörténelmi iskolák ismertetése - a kettő között a fó átfedést azt jeleni, hogy mindkettőre az olasz módszerek hatottak. A harmadik nagy fejezet $A$ szélesebb értelemben vett mikrotörténelem: az angolszászok című fejezet az angolszászangliai és amerikai mikrohistorikus történetírásról szól, melyet a szerző különállóként kezel az olasz iskola hagyományaitól, csak jóval kisebb mértékben érzi ezt az olasz hagyományok által befolyásoltnak a francia és a német iskolákhoz viszonyítva. Különös fontossága ennek az iskolának, hogy a globalizálció korában elsősorban ez határozza meg napjaink módszertanát a mikrohistória területén is. A legutolsó nagy terjedelmű fejezet pedig, melynek beszédes címe A periféria és az ezredforduló: válaszok és kérdések a mikrotörténelem aktuális kihívásait pedzegeti, egyfajta tükröt tartó módszerrel. ilyen tükör a magyar történetírás területén e témában elért eredmények, a skandináv módszerek sajátosságai, az orosz mikrotörténelem kihívásai, az affajta kihívás, hogy forrásértelmezés során a történész mit tud kihozni egy adott kontextusból, melyet akár hiányos, egymásnak ellentmondó vagy torz képet bemutató forrásai jelentenek ,, a történeti cselekvő felelössége és a történész felelössége”, az etikai dimenzió és hasonló kérdések.

Módszertani szempontból nem meglepő, hogy a kötet kiváló munka, ugyanakkor figyelmes olvasást igényel, mert a szerző gyakran több oldalon keresztül is szövi egy-egy gondolatának fonalát, mielőtt levonná a következtetéseket. Ugyanakkor téved az, aki azt gondolná, hogy a könyv kimondottan módszertani elmélkedések sorozata lenne, melyeket egy-egy példa megtámogat. A szerző rengeteg példával dolgozik, ezek ugyan az egyes szerzők és helyzetek kapcsán megfogalmazott mondanivalójának alárendeltek, - hiszen a helyzet generálja az esettanulmányt, a szerző pedig leírja azt - azonban a példák maguk is önálló életet élnek. Olyan érdekes, sokszínű, a szövegbe elrejtett példatárral rendelkezik a kötet, mint a Giovanni Battista Chiesa ördögűző vikárius esete, aki tevékenysége miatt rúgta össze a port egyházi feljebbvalóival, továbbá Cook kapitány apoteózisa és a bennszülöttek általi meggyilkolása, Gettysburg és a napóleoni oroszországi hadjárat mikrohistorikus vonatkozásai. A példák sora még folytatható lenne. Különösen megragadott Cook kapitány halálának története, amelynek során a kapitányt először - egy sor véletlen folytán - Hawaii bennszülöttei Lonó termékenységistennek nézték, és nagy tisztelettel fogadták, egy hét múlva azonban, amikor kikötni kényszerült, ellenségesen fogadták és megölték. A történetet, valamint ennek meghatározó mozgatórugóit Marshal Sahlins dolgozta ki és értelmezte Captain James Cook or the Dying God című tanulmányában, amely ugyanakkor a pozitív visszhangot de vitákat is generált szakmai körökben. Már csak ezért a rövid történet miatt is - és sok más dolog miatt - érdemes Szijártó e jelenlegi kötetét elolvasni. 